\title{
ヒトノロウイルスの代替としてマウスノロウイルスを用いた 消毒薬による不活化効果
}

\author{
清水 優子 ${ }^{1)} \cdot$ 牛島 廣治 ${ }^{1)} \cdot$ 北島 正章 2$) \cdot$ 片山 浩之 ${ }^{2)} \cdot$ 遠矢 幸伸 ${ }^{3)}$
}

\section{Murine Norovirus as a Novel Surrogate to Evaluate Disinfectants for Human Norovirus}

Yuko Shimizu ${ }^{1)}$, Hiroshi Ushijima ${ }^{1)}$, Masaaki Kitajima ${ }^{2)}$, Hiroyuki KataYama ${ }^{2)}$ and Yukinobu TohYA ${ }^{3)}$

${ }^{1)}$ Aino Health Science Center, Aino University, ${ }^{2)}$ Graduate School of Engineering, The University of Tokyo,

3) Department of Veterinary Medicine, College of Bioresource Sciences, Nihon University

(2009 年 5 月 1 日 受付 $\cdot 2009$ 年 9 月 14 日 受理)

\begin{abstract}
要 旨
ヒトノロウイルス $(\mathrm{HuNoV})$ は，未だ細胞培養系が確立されていないため，各種消毒薬の HuNoV に対する有效性について十分な知見が得られていない。そこで，HuNoVに形態学的にも 遺云学的にも類似し細胞培養可能なマウスノロウイルス $(\mathrm{MNV})$ を用い, 塩素系抢よびエタノール 系消毒薬の不活化効果を Tissue Culture Infectious Dose $50 \%\left(\mathrm{TCID}_{50}\right)$ 法を指標に評価した. 次亜 塩素酸ナトリウム抢よびジクロルイソシアヌル酸ナトリウム(塩素系消毒薬)は, $200 \mathrm{ppm}, 30$ 秒間 の接触で MNV は 99.998\% (4.8 $\log _{10}$ ) 以上不活化して検出限界以下となり, $125 \mathrm{ppm}$ の場合でも 30 秒間で $99.99 \%$ (4 $\left.\log _{10}\right)$ 以上の不活化が認められた。 $70 \mathrm{v} / \mathrm{v} \%$ エタノール， $0.18 \mathrm{w} / \mathrm{v} \%$ クロル ヘキシジングルコン酸塩含有 $72 \mathrm{v} / \mathrm{v} \%$ エタノール㧍よび $0.18 \mathrm{w} / \mathrm{v} \%$ ベンザルコニウム塩化物含有 $75 \mathrm{v} / \mathrm{v} \%$ エタノールは，30 秒間の接触で検出限界以下までウイルス感染価を低下させた.

本研究で対象とした 2 種類の塩素系消毒薬は, いずれも終濃度 $125 \mathrm{ppm}$ で高い MNV 不活化効 果を示した. また， 3 種類のエタノール系消毒薬については, エタノール濃度 $70 \mathrm{v} / \mathrm{v} \%$ 以で使用 すれば，いずれも短時間で MNV の不活化が達成できることが分かった．以上の結果から，これ らの市販の消毒薬は HuNoV に対しても高い不活化効果を有することが期待され，ノロウイルス感 染症の発生制御および拡大防止の感染対策を目的とした環境用消毒薬として有用であると考元られ る.
\end{abstract}

Key words : ノロウイルス感染症, マウスノロウイルス, 消毒薬, 不活化

\section{はじめに}

ヒトノロウイルス(Human norovirus : HuNoV)は, ヒトーヒト感染抢よび二枚貝などの契食による経口感染 によりヒトに感染し, 下痢, 嘔吐および発熱などの症状 を引き起こす1,2)ことが知られている．乳幼児から高齢 者に至るまで幅広い年齢層のヒトに感染し, 特に乳幼児 では初冬に全国で一斉に流行が発生する傾向がある。 HuNoV の感染力は非常に強く, ごく少量のウイルス㨫

1) 藍野大学藍野健康科学センター, 2) 東京大学大学院工学系研 究科, ${ }^{3)}$ 日本大学生物資源科学部獣医学科
取でも感染が成立するそそのため，完全な感染対策は極 めて困難であり，施設内での HuNoV 集団感染事例が頻 繁に報告されているのが現状である。ここ数年， $\mathrm{HuNoV}$ 感染者の報告数は増加傾向にあり, 大きな社会 問題となってきている. HuNoV の感染抢よび流行を阻 止するためには，有効な治療薬打よび消毒薬の開発が必 要不可欠であるが，HuNoV は未だ効率良く増殖させる ことのできる細胞培養系が確立されていないため, これ らの開発抢よび効果の評価が困難な状況にある1,22.

ノロウイルス (Norovirus : NoV) はカリシウイルス科 に属し, 直径約 $38 \mathrm{~nm}$ の小型の一本鎖 $(+)$ RNA ウイ 
ルスである. NoV 属は現在 Genogroup I (GI) から GV までの 5 つの Genogroupに分類されており，これまで ヒトへの感染が報告されている Genogroup は GI, GII および GIVである11.

マウスノロウイルス(Murine norovirus : MNV)は, 2003 年に初媇米国の研究施設に打ける免疫系ノック アウトマウスから見出され，ノロウイルス属の GVに分 類されている.そしてこの MNVは, 細胞培養により 感染力価を測定することが可能であり, 細胞培養が可能 なウイルスの中で HuNoVに最も近縁なウイルスである ことから新たな代替ウイルスとして急速に注目を集めて いる.わが国においても研究用の健常マウスから MNV が分離・同定された ${ }^{3)}$. 近年, 世界中の研究施設で研究 用マウスからの MNVの分離報告が相次いでいるが, これまで分離されている全ての MNV 株は同一血清型 である4).

本研究では, 国内で分離された $\mathrm{MNV}$ を $\mathrm{HuNoV}$ の代 替ウイルスとして使用し, MNVに対する各種汎用消毒 薬の不活化効果を解析した. 消毒薬として, 塩素系消毒 薬(次亜塩素酸ナトリウム拈よ゙ジクロルイソシアヌル 酸ナトリウム), エタノール，クロルヘキシジングルコ ン酸塩含有エタノールおよびベンザルコニウム塩化物含 有エタノールを用いた. 消毒薬との接触によるウイルス の感染力価の消長を解析し, これらの消毒薬の MNV に対する不活化効果を検証した.

\section{材料と方法}

1. 使用したウイルス株およびウイルス液の作製法 国内に打いて分離された $\mathrm{MNV}(\mathrm{S} 7-\mathrm{PP} 3$ 株)を用い た．マウスのマクロファージ由来細胞株である RAW
264.7 細胞 (ATCC TIB-71) に MNV を感染させて培養 し, 3 回凍結融解を繰り返した後, $800 \mathrm{~g}$ で 15 分間の 遠心分離を行った。 上清をセルロースアセテート膜 (孔径 $0.2 \mu \mathrm{m}$, Advantec) でろ過し, 分注後 $-80^{\circ} \mathrm{C}$ で保 存した。作製したウイルス液中のウイルス濃度は $10^{6-7}$ Tissue Culture Infectious Dose 50\% $\left(\mathrm{TCID}_{50}\right) / 50 \mu \mathrm{L}$ で あった。

\section{2. 使用した消毒薬}

表 1 に, 使用した消毒薬の種類および MNVとの反 応条件をまとめた. 本研究では, 塩素系消毒薬 2 種類 とエタノール系消毒薬 3 種類 (合計 5 種類)の市販の消 毒薬について，その MNV 不活化効果を検証した。

塩素系消毒薬として, 次亜塩素酸ナトリウム (sodium hypochlorite ; 化学式 $\mathrm{NaOCl}$; 商品名「ミルトン」 [杏林製薬株式会社]) 抢よびジクロルイソシアヌル酸 ナトリウム (dichloroisocyanuric acid sodium ; 化学式 $\mathrm{C}_{3} \mathrm{O}_{3} \mathrm{~N}_{3} \mathrm{Cl}_{2} \mathrm{Na}$; 商品名「ミルトン $\mathrm{CP} 」[$ 杏林製薬株式会 社）を使用した。消毒薬中の遊離塩素濃度は, $N, N$ diethyl-p-phenylenediamine (DPD) 粉末 (Hach 社) および 水質分析計 DR/890 (Hach 社)を用いた DPD 法により 測定した.

エタノール系消毒薬として, エタノール (ethanol; 化 学式 $\mathrm{C}_{2} \mathrm{H}_{5} \mathrm{OH}$; エタノール含有量 76.9-81.4 vol\% ; 商 品名「消毒用エタノール」[吉田製薬株式会社]), $0.2 \mathrm{w} /$ $\mathrm{v} \%$ クルヘキシジングルコン酸塩含有 $80 \mathrm{v} / \mathrm{v} \%$ エタ ノール (chlorhexidine gluconate; 化学式 $\mathrm{C}_{22} \mathrm{H}_{30} \mathrm{Cl}_{2} \mathrm{~N}_{10}$. $2 \mathrm{C}_{6} \mathrm{H}_{12} \mathrm{O}_{7}$; 商品名「ヒビソフト」[大日本住友製薬株 式会社]）抢よび $0.2 \mathrm{w} / \mathrm{v} \%$ ベンザルコニウム塩化物含有 $83 \mathrm{v} / \mathrm{v} \%$ エタノール (benzalkonium chloride ; 化学式 $\left[\mathrm{C}_{6} \mathrm{H}_{5} \mathrm{CH}_{2} \mathrm{~N}\left(\mathrm{CH}_{3}\right)_{2} \mathrm{R}\right] \mathrm{Cl}\left(\mathrm{R}=\mathrm{C}_{8} \mathrm{H}_{17} \sim \mathrm{C}_{18} \mathrm{H}_{37}\right)$; 商品名

表 1 消毒薬の種類と MNV との反応条件

\begin{tabular}{|c|c|c|c|c|}
\hline & 消 毒 薬 & Reaction conc. & MNV : 消毒薬 & 反応停止法 \\
\hline \multirow{4}{*}{ 塩 } & 次亜塩素酸ナトリウム & $50 \mathrm{ppm}$ & $1: 1$ & チオ硫酸ナトリウム \\
\hline & & $125 \mathrm{ppm}$ & $1: 1$ & \\
\hline & & 200 ppm & $1: 1$ & \\
\hline & & 1000 ppm & $1: 1$ & \\
\hline \multirow{4}{*}{$\begin{array}{l}\text { 素 } \\
\text { 系 }\end{array}$} & ジクロルイソシアヌル酸ナトリウム & $50 \mathrm{ppm}$ & $1: 1$ & チオ硫酸ナトリウム \\
\hline & & $125 \mathrm{ppm}$ & $1: 1$ & \\
\hline & & 200 ppm & $1: 1$ & \\
\hline & & 1000 ppm & $1: 1$ & \\
\hline \multirow{6}{*}{$\begin{array}{l}\text { 工 } \\
\text { 夕 } \\
\text { J } \\
\text { 先 } \\
\text { 系 }\end{array}$} & エタノール & $40 v / v \%$ & $1: 1$ & 希釈 $(1,000$ 倍) \\
\hline & & $70 v / v \%$ & $1: 9$ & \\
\hline & クロルヘキシジングルコン酸塩含有エタノール & 0.1 w/v\% (40 v/v\%エタノール) & $1: 1$ & 希釈 $(1,000$ 倍 $)$ \\
\hline & & $0.18 \mathrm{w} / \mathrm{v} \%$ (72 v/v\%エタノール) & $1: 9$ & \\
\hline & ベンザルコニウム塩化物含有エタノール & 0.1 w/v\% (42 v/v\%エタノール) & $1: 1$ & 希釈 $(1,000$ 倍 $)$ \\
\hline & & $0.18 \mathrm{w} / \mathrm{v} \%$ (75 v/v\%エタノール) & $1: 9$ & \\
\hline
\end{tabular}



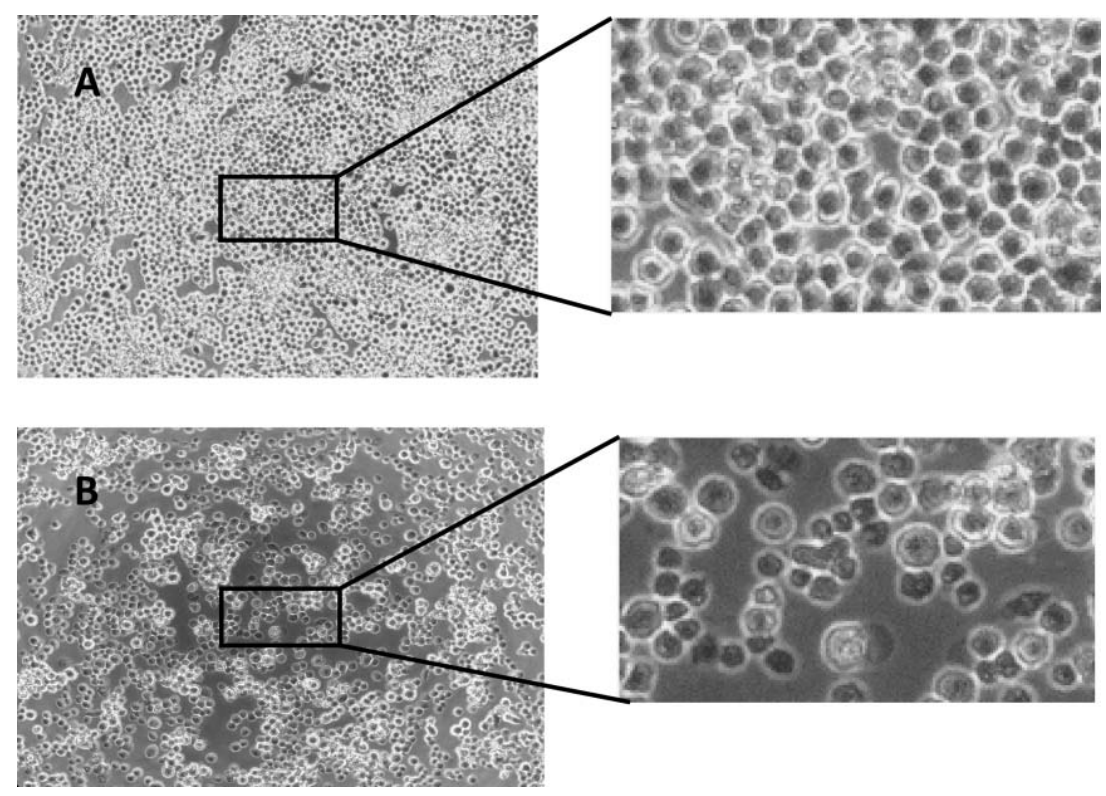

図 1 MNV 感染による細胞変性効果 (CPE)

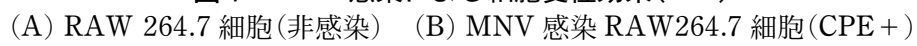

「ウエルパス ${ }^{\circledR} 」$ 丸石製薬株式会社])を使用した

\section{3. ウイルス感染力価の測定と生残率の算出}

各消毒薬を表 1 に示した濃度となるようにそれぞれ調 製し，MNVに添加し，十分に混和することで MNVを 消毒薬と接触させた. 所定時間 $(0.5,1,2,4,8,15,30$, 60 分)経過後, 表 1 に示した方法で速やかに反応を停止 させた。すなわち, 塩素系消毒薬はチオ硫酸ナトリウム $\left(\mathrm{Na}_{2} \mathrm{~S}_{2} \mathrm{O}_{3}\right)$ を用いて中和し, その他は $10 \%$ 牛胎児血清含 有 Dulbecco's Modified Eagle Medium (DMEM)培地で 1000 倍希釈することで反応を停止させた. クロルへキ シジングルコン酸塩およびベンザルコニウム塩化物含有 エタノールについてはウイルス感染力価測定の際の細胞 毒性を考慮し，さらに 10 倍希釈した。

各反応液は DMEM 培地で 10 段階希釈し, RAW 264.7 細胞を培養した 96 well マイクロプレートに各希 釈液 $50 \mu \mathrm{L} /$ well を 4 well ずつ接種し, 炭酸ガス培養装 置 $\left(37^{\circ} \mathrm{C} ; 5 \% \mathrm{CO}_{2}\right)$ 内で培養した. 4 日間培養後, 顕微 鏡下で細胞変性効果 (cytopathic effect : CPE)の出現を 観察し, $\mathrm{TCID}_{50}$ 法によってウイルスの感染力価を定量 した. 図 1 に, MNV 非感染の RAW 264.7 細胞の顕微 鏡観察像とともに, MNV 感染により引き起こされた RAW 264.7 細胞の CPE の顕微鏡観察像を示す. 約 90 \%コンフルエント時の MNV 非感染 RAW 264.7 細胞 は, 顕微鏡下で光沢をもつ円形に近い形状として観察さ れる(A)に対し, MNVに感染した RAW 264.7 細胞に は光沢がなくなり萎縮する激しい細胞損傷および細胞損 傷に伴う細胞間隙の顕著な増加が認められる(B)ため, MNV 感染による CPE の出現の有無が容易に判定可能
であった。

消毒薬との反応前のウイルス感染力価 $\mathrm{N}_{0}\left(\mathrm{TCID}_{50}\right)$ に 対する所定条件に打ける消毒薬による反応後のウイルス 感染力価 $\mathrm{N}\left(\mathrm{TCID}_{50}\right)$ の割合 $\mathrm{N} / \mathrm{N}_{0}$ を算出し, 生残率と した. 表 1 に示した各濃度および各反応時間のそれぞれ について全て 3 回の実験を行い, 各実験条件に打ける $\mathrm{MNV}$ の生残率の平均值を算出した.

\section{結果}

1. 次亜塩素酸ナトリウムの MNV 不活化効果

図 $2(a)$ ，次亜塩素酸ナトリウムと接触させた場合 の MNVの生残率の経時变化を示す。濃度 $1000 \mathrm{ppm}$ 打 よび $200 \mathrm{ppm}$ の場合，30 秒間の接触により MNVは $99.998 \%\left(4.8 \log _{10}\right)$ 以上不活化して検出下限以下となっ た。濃度 $125 \mathrm{ppm}$ の場合， 30 秒間の接触で MNV は 99.99\% $\left(4 \log _{10}\right)$ 以上不活化し，8 分間の接触で 99.999 $\%\left(5 \log _{10}\right)$ 以上不活化して検出下限以下となった．濃度 $50 \mathrm{ppm}$ の場合は，1 分間の接触で $99 \%\left(2 \log _{10}\right)$ 程度不 活化したが，その後は極めて緩やかに不活化し，60 分 間の接触後の不活化率は $99.8 \%\left(2.7 \log _{10}\right)$ であった.

次亜塩素酸ナトリウム濃度が $50 \mathrm{ppm}$ 以下の場合には 長時間の接触後もウイルスの一部が生残する可能性があ るが, 濃度 $125 \mathrm{ppm}$ 以上の次亜塩素酸ナトリウムと接 触させた場合に 30 秒間の接触で $99.99 \%\left(4 \log _{10}\right)$ 以上 のウイルス不活化が期待できる.

\section{2. ジクロルイソシアヌル酸ナトリウムの MNV 不活 化効果}

図 2(b)に，ジクロルイソシアスル酸ナトリウムと接 


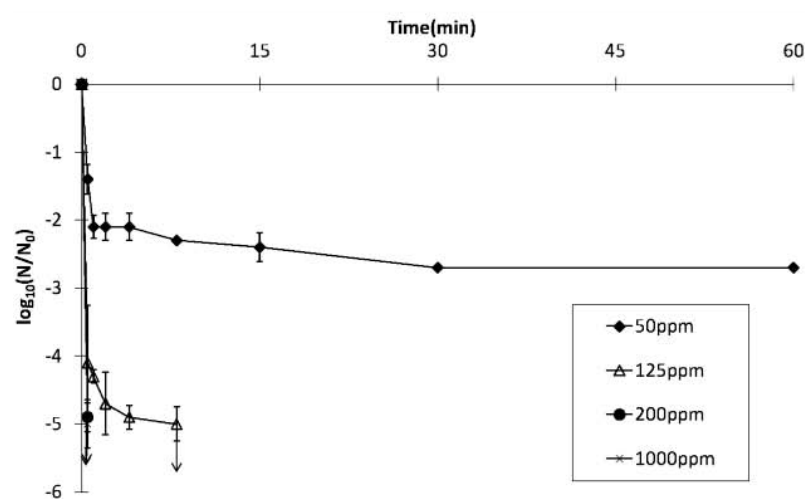

(a) 次亜塩素酸ナトリウム

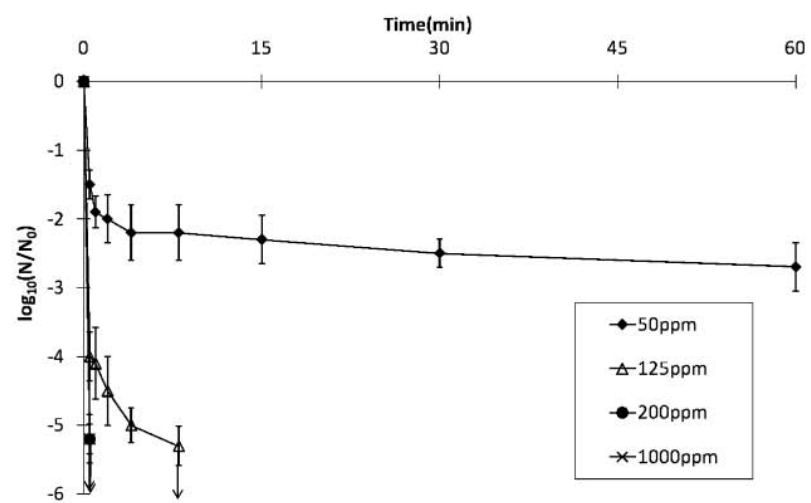

(b) ジクロルイソシアヌル酸ナトリウム

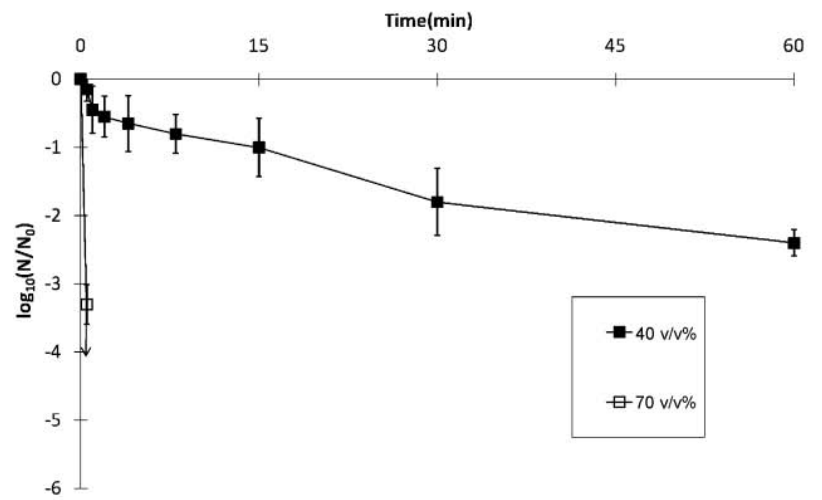

(c) エタノール

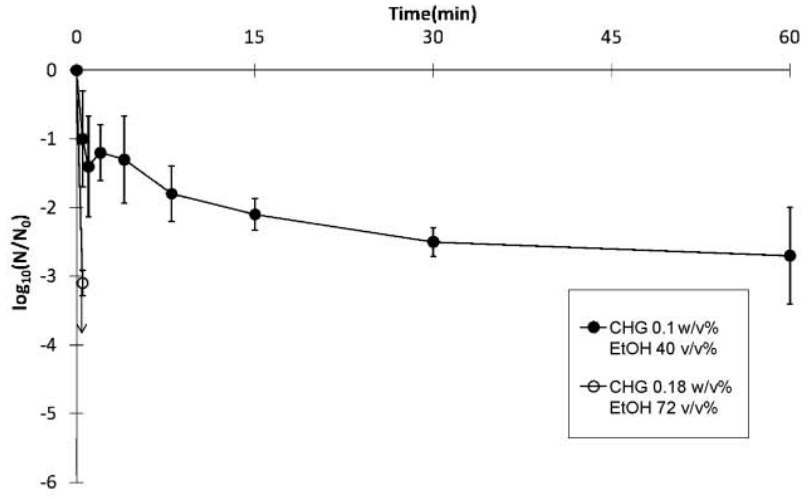

(d) クロルヘキシジングルコン酸塩含有エタノール

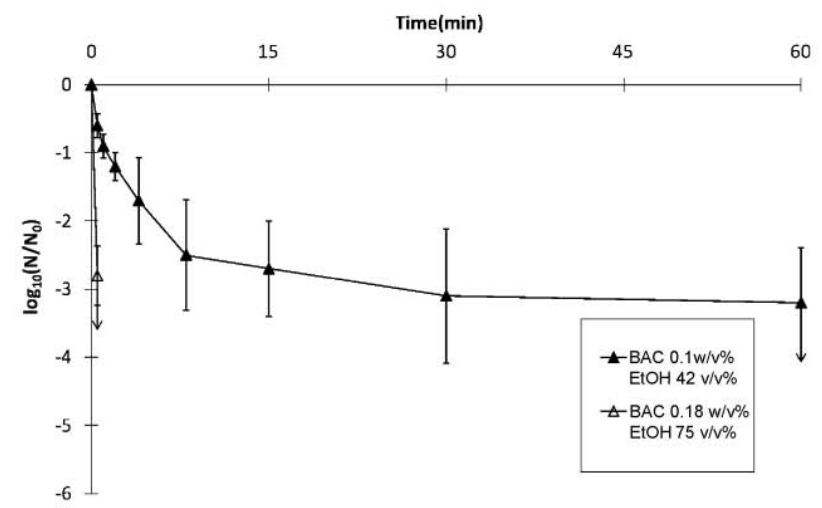

(e) ベンザルコニウム塩化物含有エタノール

図 2 消毒薬による MNV の生残率の経時変化

横軸は MNV と消毒薬との反応時間, 縦軸は $M N V$ 生残率 $\log _{10}\left(\mathrm{~N} / \mathrm{N}_{0}\right)$ を示す. 下向き矢印以降は検出限界以下となる.

触させた場合の MNVの生残率の経時変化を示す，濃 度 $200 \mathrm{ppm}$ 抢よび $1000 \mathrm{ppm}$ の場合には，30 秒間の接 触により MNV は $99.999 \%\left(5 \log _{10}\right)$ 以上不活化して検 出限界以下となった。濃度 $125 \mathrm{ppm}$ の場合には, 30 秒 間の接触で $99.99 \%\left(4 \log _{10}\right)$ 以上不活化し， 8 分間の接 触で $99.999 \%\left(5 \log _{10}\right)$ 以上不活化した. 濃度 $50 \mathrm{ppm} の$ 場合は，2 分間の接触で $99 \%\left(2 \log _{10}\right)$ 程度不活化した が，その後は極めて緩やかに不活化し，60 分間の接触 後の不活化率は $99.8 \%\left(2.7 \log _{10}\right)$ であった.

ジクロルイソシアスル酸ナトリウムと接触させた場合
の MNV の生残率の経時変化は, 次亜塩素酸ナトリウ ムと接触させた場合とほぼ同様であった(図 $2(a)(b))$. すなわち, ジクロルイソシアスル酸ナトリウム濃度が $50 \mathrm{ppm}$ 以下の場合には長時間の接触後もウイルスの一 部が生残する可能性があるが，濃度 $125 \mathrm{ppm}$ 以上のジ クロルイソシアヌル酸ナトリウムと接触させた場合に 30 秒間の接触で $99.99 \%\left(4 \log _{10}\right)$ 以上のウイルス不活化 が期待できる.

3. エタノールの MNV 不活化効果

図 2 (c)に, エタノールと接触させた場合の MNV の 
生残率の経時変化を示す。エタノール濃度 $70 \mathrm{v} / \mathrm{v} \%$ の 場合, 30 秒間の接触で $99.94 \%\left(3.3 \log _{10}\right)$ 以上不活化し て検出下限以下となった. エタノール濃度 $40 \mathrm{v} / \mathrm{v} \%$ の 場合は，エタノールとの接触による MNV の不活化は 緩やかであった. すなわち, 15 分間の接触後の不活化 率は約 $90 \%\left(1 \log _{10}\right)$ であり, 60 分間の接触後の不活化 率は $99.6 \%\left(2.4 \log _{10}\right)$ であった.

エタノール濃度が $40 \mathrm{v} / \mathrm{v} \%$ 以下の場合には長時間の 接触後もウイルスの一部が生残する可能性があるが, 濃 度 $70 \mathrm{v} / \mathrm{v} \%$ 以上のエタノールと接触させた場合には 30 秒間の接触で $99.9 \%\left(3 \log _{10}\right)$ 以上のウイルス不活化が期 待できる。

4. クロルヘキシジングルコン酸塩含有エタノールの MNV 不活化効果

図 $2(d)$, クロルヘキシジングルコン酸塩含有エタ ノールと接触させた場合の MNVの生残率の経時变化 を示す. $0.18 \mathrm{w} / \mathrm{v} \%$ クロルヘキシジングルコン酸塩含有 $72 \mathrm{v} / \mathrm{v} \%$ エタノールと接触させた場合, 30 秒間の接触 で MNV は 99.9\% (3 $\left.\log _{10}\right)$ 以上不活化して検出限界以 下となった。 $0.1 \mathrm{w} / \mathrm{v} \%$ ロルヘキシシンングルコン酸塩 含有 $40 \mathrm{v} / \mathrm{v} \%$ エタノールと接触させた場合, 30 秒間の 接触後の不活化率は $90 \%\left(1 \log _{10}\right)$ であり，その後は緩 やかに不活化して 60 分間の接触後の不活化率は $99.8 \%$ $\left(2.7 \log _{10}\right)$ であった.

$0.18 \mathrm{w} / \mathrm{v} \%$ クロルヘキシジングルコン酸塩含有 $72 \mathrm{v} /$ v\%エタノールには $99.9 \%\left(3 \log _{10}\right)$ 程度のウイルス不活 化効果が認められた.

5. ベンザルコニウム塩化物含有エタノールの MNV 不活化効果

図 $2(\mathrm{e})$ に, ベンザルコニウム塩化物含有エタノール と接触させた場合の MNVの生残率の経時変化を示す。 $0.18 \mathrm{w} / \mathrm{v} \%$ ベンザルコニウム塩化物含有 $75 \mathrm{v} / \mathrm{v} \%$ エタ ノールと接触させた場合，MNVは 30 秒間で $99.8 \%$ $\left(2.8 \log _{10}\right)$ 以上不活化し検出下限以下となった． $0.1 \mathrm{w} /$ $\mathrm{v} \%$ ベンザルコニウム塩化物含有 $42 \mathrm{v} / \mathrm{v} \%$ エタノールと 接触させた場合, 2 分間の接触で $93 \%\left(1.2 \log _{10}\right)$ 程度不 活化し，8 分間の接触で $99.6 \%\left(2.5 \log _{10}\right)$ 程度不活化し た. その後は緩やかに不活化し, 接触開始から 60 分後 には 99.9\% (3 $\left.\log _{10}\right)$ 以上不活化して検出下限以下となっ た.

ベンザルコニウム塩化物含有エタノールによる MNV の不活化効果は, クロルヘキシジングルコン酸塩含有エ タノールによる不活化効果と同程度かそれ以上であると 考えられた。

\section{考察}

本研究では, 国内で分離された $\mathrm{MNV}$ を $\mathrm{HuNoV}$ の代 替ウイルスとして使用し，MNVに対する塩素系および
エタノール系消毒薬の不活化効果を検証した.

ノロウイルス感染症は, 急性感染症であり特に慢性化 および癌化することのない疾患ではあるが, 症状が急激 であり小児および高齢者が感染すると症状が重篤になり 死に至ることもある1,2). 実際に，世界的には年間に 10 ～20 万人がノロウイルス感染症に関連する病因で死亡 していると推定されており5)，わが国でも HuNoV 感染 に伴う脱水による全身の消耗を原因とした死亡例なたは 嘔吐による窒息を原因とした死亡例が報告されている. 小児における HuNoV 感染事例では，脳症および痤攣な どの合併症を引き起こすこともある．また近年，合併症 の有無にかかわらずウイルス血症が認められることも明 らかとなってきた ${ }^{6)} . \mathrm{HuNoV}$ 感染には, 感染者の吐物 や糞便に污染された物質に手を触れることで手がウイル スに污染され，その手を介して污染された食物を契食す ることによる経口感染およびウイルスが含まれたエアロ ゾルを吸入することによる飛沫感染がある，HuNoVの 二次感染を防ぐためには，不活化に有効な消毒薬を用い て污染されている可能性のある場所に適切な消毒を施 し，その感染経路を断ち切ることが非常に重要である.

消毒薬の開発およびウイルスに対する有効性の評価を 目的とした実験では，一般にウイルスを消毒薬と接触さ せ，一定時間経過後に反応を停止した後，消毒薬との接 触によるウイルスの感染力価の消長を細胞培養法によっ て測定する. MNVの場合プラックアッセイにより感染 力価を測定することも可能であるが, MNVの培養細胞 である RAW 264.7 細胞は半付着性の細胞であることか ら, プラックアッセイが可能な他のウイルスに比べると プラック形成が容易ではない。 それに対し， TCID 50 法 では MNV の増殖に伴う明瞭な CPE が確認できるため, $\mathrm{TCID}_{50}$ 法のほうが容易かつ確実な方法である。そのた め, 本研究では $\mathrm{TCID}_{50}$ 法を用いて MNVの感染力価を 測定した．また， Real-time RT-PCRにより MNVの遺 伝子量の消長を測定することも可能であるが，遺伝子量 の低減は感染力価の低減を大きく過小評価することにな ることが知られているため, 本研究では遺伝子量の変化 の追跡は必要ないと判断し感染力価の低減のみを測定す ることとした。

$\mathrm{HuNoV}$ は効率良く増殖させることのできる細胞培養 系が確立されていない。このような状況下で，消毒実 験等に打ける $\mathrm{HuNoV}$ の代替ウイルスとしては, 同じ カリシウイルス科に属し細胞培養が可能なネコカリシ ウイルス (Feline calicivirus : FCV) およびイスカリシウ イルス(Canine calicivirus : CaCV)が広く用いられてき $た^{7 \sim 11)}$. 米国環境保護局(U.S. EPA, United States Environmental Protection Agency)は，ノロウイルス代替 として FCVを用いることを推奨しており，99.9\%(3 $\left.\log _{10}\right)$ あるいは $99.99 \%\left(4 \log _{10}\right)$ 以上の感染価が減少す 
れば抗ウイルス薬として有効であるとしている12). Duizer らの FCV, CaCV を用いた 70\%エタノール実験 では 8 分で $99 \% ， 30$ 分で $99.9 \%$ の不活化を見た。 また 次亜塩素酸ナトリウムは $\mathrm{FCV}, \mathrm{CaCV}$ ともに $30 \mathrm{ppm}$ で はあまり効果が認められなかった. $300 \mathrm{ppm}, 10$ 分では $\mathrm{CaCV}$ は 99.9\%の不活化がみられたが，FCVは $99 \%$ 以 下の不活化に留まった7)。しかしながら，FCVはノロ ウイルス属とは異なるベジウイルス属に属するウイルス であること, 及び HuNoV が腸管で増殖して粪便中に排 出されるのに対し, FCV はネコの呼吸器に感染するウ イルスであり糞便中には排出されないことなど, $\mathrm{HuNoV}$ とは異なる特性を持つため代替ウイルスとして 使用するには限界があると考えられている13).

2003 年にその存在が初めて報告された MNV は, 形 態学的にも遺伝学的にも HuNoV に類似したウィルスで あり，ノロウイルス属の Genogroup V に分類されてい る3,4,14,15). そして, この MNV は培養法により感染力 価を測定することが可能であるため, 近年 $\mathrm{HuNoV}$ の代 替ウイルスとして用いられるようになってきている.

Belliotらは，米国で分離された $\mathrm{MNV}$ (MNV-1 株)を用 いた消毒実験結果を報告しており，60\%エタノールで は 30 秒で $99.99 \%$ 以上不活化し，0.26\%活性塩素 (36 $\mathrm{mM}$ 次亜塩素酸ナトリウム)では 30 秒で $99.99 \%$ 以上不 活化したとしている16)。これらの結果から，MNV， $\mathrm{CaCV}, \mathrm{FCV}$ の代替ウイルスにより多少の差が見られる ことがわかる.

我々の結果では, 塩素系消毒薬は $125 \mathrm{ppm}, 30$ 秒で 99.99\%以上の不活化効果が見られた. 厚生労働省が推 奨している $200 \mathrm{ppm}$ では 30 秒で 99.999\%以上の高い 不活化が見られた．DPD法により遊離塩素濃度を測定 したところ, 本研究で使用した次亜塩素酸ナトリウムお よびジクロルイソシアスル酸ナトリウム中に含まれる塩 素は遊離塩素が大半を占めており, 結合塩素はほとんど 検出されなかった(data not shown).

北島らは, 水道水中の HuNoVの塩素消毒耐性の解明 を目的として本研究よりも低い初期遊離塩素濃度 $(0.1$ および $0.5 \mathrm{ppm}$ )で MNV の不活化効果を調べている. また, この報告では, 水試料中に添加した遊離塩素濃度 の経時変化を追跡しているが, 水中の遊離塩素濃度は時 間経過とともに減少する傾向が認められたとしてい る ${ }^{17)}$. その原因としては, 水試料中に存在した塩素消 費物質の影響が考えられる. 本研究では, 消毒薬との接 触中の遊離塩素濃度の経時変化は調べていないが, ウイ ルス液中に含まれる細胞培養用培地由来の有機物等によ り塩素が消費されたため時間経過とともに消毒効果が低 減したものと考えられる. エタノール系消毒薬の場合 は，培地由来成分によるエタノールの消費およびエタ ノールの気化により時間経過とともに消毒効果が低減し
たものと考えられる。

エタノールは $70 \mathrm{v} / \mathrm{v} \%$ 抢よび $40 \mathrm{v} / \mathrm{v} \%$ の 2 つの濃度 に設定し不活化実験を行った。エタノール系消毒薬の場 合は, 塩素系消毒薬と比較すると不活化に時間がかかっ た. 特に, $40 \mathrm{v} / \mathrm{v} \%$ の場合は十分な不活化効果は認めら れなかった．クロルヘキシジングルコン酸塩含有エタ ノールとベンザルコニウム塩化物含有エタノールはいず れも約 $80 \mathrm{v} / \mathrm{v} \%$ エタノールを含んでいるが，エタ ノール単独の場合に比ベクロルヘキシジングルコン酸塩 およびベンザルコニウム塩化物が不活化効果を増大させ ていると考えられた．エタノール系消毒薬については， エタノール濃度 $70 \mathrm{v} / \mathrm{v} \%$ 以上で十分量使用すれば，短 時間 (30 秒以内) で MNV に対して不活化作用が認めら れた。

塩素系の消毒薬は, 低い濃度では水道水の消毒に用い られる.我が国の水道法では, 水道水の微生物学的安全 性の確保のため給水栓末端で $0.1 \mathrm{mg} / \mathrm{L}$ 以上の遊離塩素 濃度を保つことが定められている。 また， ジクロルイソ シアスル酸ナトリウムは固形塩素系消毒薬として有用で ある。一方，エタノール系消毒薬は，手指の消毒等に便 利であり危険性が少ないため広く使用されている．塩素 系消毒薬およびエタノール系消毒薬のそれぞれの特徵を 理解し, 効果のある濃度, 時間で用いることが重要であ る.

この報告は, $\mathrm{HuNoV}$ の新たな代替ウイルスとして MNV を使用し, 市販の塩素系 (2 種類) およびエタノー ル系 (3 種類) 消毒薬による不活化効果を検討した国内で 初めての報告である. 本研究により得られた結果から, 今回評価対象とした消毒薬は, HuNoVに対しても高い 不活化効果を有することが期待され，ノロウイルス感染 症対策を目的とした環境用消毒薬として使用可能である と考えられる.

利益相反について: 本研究は, 杏林製薬株式会社より消毒薬の 提供を受けた.

文献

1）牛島廣治, 西村修一：ノロウイルス感染症. 最新医 2008; 63(3)増刊号：617-35.

2）国立感染症研究所感染症情報センター：ノロウイル 又感染症. http: //idsc.nih.go.jp / disease / norovirus / index.html

3）遠矢幸伸：マウスノロウイルス。 ウイルス性下痢症研 究会第 20 回学術集会抄録集 2007, p. 4.

4) Thackray LB, Wobus CE, Chachu KA, Liu B, Alegre $\mathrm{ER}$, Henderson KS, et al.: Murine noroviruses comprising a single genogroup exhibit biological diversity despite limited sequence divergence. J Virol 2007; 81 (19): 10460-73.

5) Patel MM, Widdowson MA, Glass RI, Akazawa K, Vinjé J, Parashar UD: Systematic literature review of 
role of noroviruses in sporadic gastroenteritis. Emerg Infect Dis 2008; 14 (8): 1224-31.

6) Takanashi S, Hashira S, Matsunaga T, Yoshida A, Shiota T, Tung PG, et al:: Detection, genetic characterization, and quantification of norovirus RNA from sera of children with gastroenteritis. J Clin Virol 2009; 44(2): 161-3.

7) Duizer E, Bijkerk P, Rockx B, De Groot A, Twisk F, Koopmans M: Inactivation of caliciviruses. Appl Environ Microbiol 2004; 70 (8): 4538-43.

8) 森 功次, 林 志直, 野口やよい, 甲斐明美, 大江香 子, 酒井沙知, 他 : Norovirus $の$ 代替指標として Feline Calicivirus を用いた手洗いによるウイルス除去効 果の検討. 感染症誌 2006; 80(5): 496-500.

9）森 功次, 林 志直, 秋場哲哉, 野口やよい, 吉田靖 子, 甲斐明美, 他: Norovirus の代替指標として Feline Calicivirus を用いた，手指に添加したウイルスの 速乾性消毒剤による擦式消毒, ウェットティッシュに よる清拭抢よび機能水を用いた手洗いによる除去抢よ び不活化効果の検討. 感染症誌 2007; 81(3): 249-55.

10）高木弘隆, 杉山和良 : ネコカリシウイルス (FCV)を代 替としたノロウイルス $(\mathrm{NV})$ 不活化効果の検討. 医と 薬学 2007; 57(3): 311-2.

11）隅下佑一, 加藤由美, 高本一夫, 古田太郎, 西尾 治, 木村博一：ノロウイルス代替のネコカリシウイル スおよび各種微生物に有効なエタノール製剤の開発. 防菌防徽 2007; 35(11): 725-32.
12) U.S. Environmental Protection Agency: Confirmatory virucidal effectiveness test using feline calicivirus as surrogate for Norovirus. http://www.epa.gov/oppad001/pdf_files/confirmatory_virucidal_test.pdf

13) Wobus CE, Thackray LB, Virgin HW 4th: Murine norovirus: a model system to study norovirus biology and pathogenesis. J Virol 2006; 80 (11): 5104-12.

14) Karst SM, Wobus CE, Lay M, Davidson J, Virgin HW 4th: STAT1-dependent innate immunity to a Norwalklike virus. Science 2003; 299 (5612): 1575-8.

15) Wobus CE, Karst SM, Thackray LB, Chang KO, Sosnovtsev SV, Belliot G, et al.: Replication of Norovirus in cell culture reveals a tropism for dendritic cells and macrophages. PLoS Biol 2004; 2(12): 2076-84.

16) Belliot G, Lavaux A, Souihel D, Agnello D, Pothier P: Use of murine norovirus as a surrogate to evaluate resistance of human norovirus to disinfectants. Appl Environ Microbiol 2008; 74(10): 3315-8.

17）北島正章，遠矢幸伸，松原康一，原本英司，宇田川悦 子，片山浩之，他：新たな代替指標としてマウス分離 株を用いた水道水中のノロウイルスの塩素耐性の解 明. 環境工学研究論文集 $2008 ; 45: 361-70$.

〔連絡先 : =150-0002 東京都踏谷区潞谷 2-17-3-4F 藍野大学藍野健康科学センター 牛島廣治 E-mail: ushijima-hiroshi@jcom.home.ne.jp]

\title{
Murine Norovirus as a Novel Surrogate to Evaluate Disinfectants for Human Norovirus
}

\author{
Yuko Shimizu $^{1)}$, Hiroshi Ushijıma ${ }^{1)}$, Masaaki Kitajıma ${ }^{2)}$, Hiroyuki Katayama ${ }^{2)}$ and Yukinobu TohyA ${ }^{3)}$ \\ 1) Aino Health Science Center, Aino University, ${ }^{2)}$ Graduate School of Engineering, The University of Tokyo, \\ ${ }^{3)}$ Department of Veterinary Medicine, College of Bioresource Sciences, Nihon University
}

\begin{abstract}
Human noroviruses $(\mathrm{HuNoVs})$ are the major cause of acute viral gastroenteritis worldwide. However, no cell culture system for HuNoVs is available, so little is known about the efficacy of various disinfectants against HuNoVs. Cultivable murine norovirus (MNV) was used as a novel surrogate for $\mathrm{HuNoVs}$ to evaluate the efficacy of five types of chlorine-based and alcohol-based commercial disinfectants to $\mathrm{MNV}$ using the $\mathrm{TCID}_{50}$ method. MNV was inactivated to more than 99.998 $\%\left(4.8 \log _{10}\right)$ and reached the detection limit by $200 \mathrm{ppm}$ of chlorine-based disinfectants, sodium hypochlorite and dichloroisocyanuric acid sodium, with contact time of 30 seconds. Moreover, MNV was inactivated at $99.99 \%\left(4 \log _{10}\right)$ using chlorine-based disinfectants at a final dilution concentration of $125 \mathrm{ppm}$ with contact time of 30 seconds. Three types of alcohol-based commercial disinfectants, $70 \mathrm{v} / \mathrm{v} \%$ ethanol, $0.18 \mathrm{w} / \mathrm{v} \%$ chlorhexidine gluconate with $72 \mathrm{v} / \mathrm{v} \%$ ethanol, and $0.18 \mathrm{w} / \mathrm{v} \%$ benzalkonium chloride with $75 \mathrm{v} / \mathrm{v} \%$ ethanol, all reduced MNV to titers below the detection limit with contact time of 30 seconds. Chlorine-based disinfectants showed great efficacy against MNV even if diluted to $125 \mathrm{ppm}$. In addition, alcohol-based disinfectants had adequate efficacy against MNV if used without dilution (ethanol concentrations of more than $70 \mathrm{v} / \mathrm{v} \%$ ). These results suggest that these disinfectants can inactivate HuNoVs. The five types of commercially available disinfectants tested here can be used to prevent norovirus infection.
\end{abstract}

Key words : norovirus infection, murine norovirus, disinfectant, inactivation 